\title{
Educação e vivências interculturais: contribuições dos círculos de cultura em práticas libertadoras
}

\author{
Education and intercultural experiences: contributions of culture \\ circles in liberating practices
}

\section{Educación y experiencias interculturales: contribuciones de los círculos culturales en las prácticas de liberación}

\author{
Giselle Moura Schnorr ${ }^{1}$ \\ https://orcid.org/0000-0003-0396-8693 \\ Joana D'Arc Vaz \\ https://orcid.org/0000-000 I-6089-3857 \\ Almir Sandro Rodrigues ${ }^{3}$ \\ https://orcid.org/0000-0003-0365-9364
}

\begin{abstract}
Resumo: Este artigo apresenta resultados parciais de um trabalho coletivo que articula ações de pesquisa e de extensão adotando Círculos de Cultura como princípio pedagógico e epistemológico no campo educativo. Nestas iniciativas, pesquisa e extensão são assumidas num exercício de retroalimentação, de modo dialético e dialógico, acerca de questões concretas. O estudo bibliográfico aproximou a Pedagogia Libertadora de Paulo Freire e o Programa de Transformação Intercultural da Filosofia proposto por Raúl Fornet-Betancourt, tendo como questão convergências entre interculturalidade e dialogicidade na construção de "inéditos viáveis". Aspectos do
\end{abstract}

\footnotetext{
'Doutora em Educação pela Universidade de São Paulo (USP). Pesquisadora do Núcleo de Estudos e Pesquisas sobre Ensino de Filosofia (NESEF/UFPR). Coordenadora do Programa de Extensão Coletivo Paulo Freire: Filosofia, Educação e Cultura (UNESPAR). Professora de Filosofia e do Programa de Mestrado Profissional em Filosofia (PROF-FILO) da UNESPAR, campus de União da Vitória. E-mail: giselleschnorr@gmail.com

${ }^{2}$ Pós-doutora em Educação pela Universidade Estadual de Ponta Grossa (UEPG). Professora do Curso de Pedagogia da Universidade Estadual do Paraná (UNESPAR), campus de União da Vitória/PR. Pesquisadora do Grupo de Estudos e Pesquisas em Práxis Educativa (GEPPRAX); Grupo de Estudos e Pesquisas História e Sociedade nos Campos Gerais-PR (HISTEDBR/UEPG); Grupo Transformações do Mundo do Trabalho (TMT/UFSC); e do Programa de Extensão Coletivo Paulo Freire: Filosofia, Educação e Cultura (UNESPAR). Email: darcvaz.13@gmail.com

${ }^{3}$ Doutor em Sociologia pela Universidade Federal do Paraná (UFPR). Professor do Curso de Pedagogia da Universidade Estadual do Paraná (UNESPAR), campus de União da Vitória. Pesquisador do Grupo de Estudos e Pesquisas em Práxis Educativa (GEPPRAX) da UNESPAR; do Núcleo de Estudos e Pesquisas sobre Ensino de Filosofia (NESEF/UFPR); e, do Programa de Extensão Coletivo Paulo Freire: Filosofia, Educação e Cultura (UNESPAR). E-mail: filorodrigues@yahoo.com.br
}

Olhar de professor, Ponta Grossa, v. 24, p. I-27, e-16773.018, 2021.

Disponível em <https://revistas2.uepg.br/index.php/olhardeprofessor> 
pensamento destes autores e algumas iniciativas em curso são tratados no escopo deste trabalho. Avaliamos que intervir no instituído, provocar deslocamentos em favor de um novo ethos é possível e que Círculos de Cultura se apresentam com potencial epistêmico, ético e político com contribuições às práticas interculturais libertadoras, em contraponto às formas de embrutecimento do outro e de reprodução de mentalidades colonizadas.

Palavras-chaves: Filosofia Intercultural. Pedagogia Libertadora. Círculos de Cultura.

\begin{abstract}
This article presents partial results of a collective project that articulates research and extension actions, adopting Culture Circles as a pedagogical and epistemological principle in the educational field. In this initiative, research and extension are carried out as an exercise of constant improvement, by employing a dialectical and dialogical method to approach concrete questions. The bibliographic study joined Paulo Freire's Pedagogy of Liberation and the Intercultural Transformation of Philosophy Program proposed by Raúl FornetBetancourt focusing on the convergence between interculturality and dialogicity in the construction of "viable unpublished". Aspects of these authors' thoughts and some current initiatives are addressed within the scope of this article. We conclude that it is possible to intervene in the instituted, to cause displacements in favour of a new ethos, and that Circles of Culture present epistemic, ethical and political potential. These actions contribute to liberating intercultural practices as opposed to forms of brutalization of the other and reproduction of colonized mentalities.
\end{abstract}

Keywords: Intercultural Philosophy. Liberating Pedagogy. Culture Circles.

Resumen: Este artículo presenta resultados parciales de un trabajo colectivo, que articula acciones de investigación y extensión adoptando los Círculos de Cultura como principio pedagógico y epistemológico en el campo educativo. En estas iniciativas, la investigación y la extensión asumen un ejercicio de retroalimentación, de manera dialéctica y dialógica, sobre temas concretos. El estudio bibliográfico aproximó a la Pedagogía Liberadora, de Paulo Freire, y al Programa de Transformación Intercultural de la Filosofía, propuesto por Raúl FornetBetancourt, hacia la convergencia entre interculturalidad y dialogicidad en la construcción de "inéditos viables". Se tratan en el trabajo aspectos del pensamiento de estos autores y algunas iniciativas en curso. Evaluamos que es posible intervenir en lo instituido, provocar el desplazamiento a favor de un nuevo ethos, y que los Círculos Culturales presentan potencial epistémico, ético y político con contribuciones a las prácticas interculturales liberadoras, en contraposición a las formas de embrutecimiento del otro y de reproducción de mentalidades colonizadas.

Palabras clave: Filosofía Intercultural. Pedagogía Liberadora. Círculos de Cultura.

\title{
Introdução
}

No momento em que escrevemos este artigo vivemos a maior pandemia dos últimos 100 anos e o Brasil contabiliza mais de 100 mil mortes oficiais devido à Covid-19. O ato de escrever está implicado com o de re-existir, de respirar, de manter a vida e a esperança. A pandemia de Covid- 19 que afeta o mundo todo tem, na América Latina e no Brasil, marcas próprias de uma tragédia que se agudiza com as históricas desigualdades sociais deste lado do globo.

Diante de coletividades e indivíduos que sofrem múltiplos danos na saúde física e mental, profunda crise socioeconômica e perdas de vidas, temos assistido atônitos a líderes políticos expressarem uma enorme incapacidade de estabelecer diálogo em busca de soluções em defesa da vida. Trata-se de um tempo de vertigens em meio ao mundo globalizado, interconectado, sob o poder de um sistema econômico, político e social disfuncional. À crise econômica, crise do capital, soma-se à crise sanitária que desvela as profundas desigualdades históricas, em suas complexas faces, tais como 
do racismo estrutural ${ }^{4}$, do sexismo institucionalizado ${ }^{5}$, da concentração de riquezas e destruição do meio ambiente. A crise política, do modelo liberal e neoliberal, revela a incapacidade de instituições responderem aos problemas pela via da democracia, sem o uso da violência.

A globalização é uma consequência da modernidade, do colonialismo e do imperialismo em favor da reprodução do capital. Um processo de desenvolvimento desigual que atualmente se efetiva com políticas neoliberais, sob a direção de empresas multinacionais ou consórcios internacionais, com impactos nas condições de vida de todo planeta, também, com consequências nas transformações culturais, desterritorializando e destradicionalizando culturas (FORNET-BETANCOURT, 200I).

A globalização como perversidade é sistêmica e se manifesta na reprodução da pobreza, na fome, no desemprego, na violência no cotidiano de periferias urbanas e do campo e "tem relação com a adesão desenfreada aos comportamentos competitivos que atualmente caracterizam as ações hegemônicas" (SANTOS, 2002, p. 19-20). Este mundo da mercadoria aniquila diversidades e se consagra como epistemologia do caçador (PANIKKAR apud FORNET-BETANCOURT, 200I), reduzindo capacidades humanas ao possuir e/ou consumir.

A concepção moderna-ocidental como modelo explicativo, pretensamente único, se afirmou a partir das grandes navegações, ao final do século XV, pois o "ego cogito moderno foi antecedido em mais de um século pelo ego conquiro (eu conquisto)" (DUSSEL, 2005, p. 63). Trata-se de modos de pensar, de estar, se relacionar consigo e com chamados "outros", inaugurando o eurocentrismo, que coloca a Europa como centro e classifica todas as outras culturas como "periferia".

A educação e os processos de escolarização historicamente instituídos estão banhados deste tempo histórico que, em última análise, remontam a modernidade e a reprodução do capitalismo. Releituras críticas da modernidade como um fenômeno intra-europeu, colonial e violento são necessárias, tal como sintetizado por Dussel (2005, p. 64):

Se a Modernidade tem um núcleo racional ad intra forte, como "saída" da humanidade de um estado de imaturidade regional, provinciana, não planetária, essa mesma Modernidade, por outro lado, ad extra, realiza um processo irracional que se oculta a seus próprios olhos. Ou seja, por seu conteúdo secundário e negativo mítico, a "Modernidade" é justificativa de uma práxis irracionais de violência. $O$ mito poderia ser assim descrito:

\footnotetext{
${ }^{4}$ Termo que enfatiza a compreensão de que o racismo é um sistema institucionalizado, resultado de um processo histórico e político no qual condiçães de subalternidade ou de privilégio de sujeitos racializados são estruturalmente reproduzidas. Considerar o racismo como estrutural não exime a responsabilidade das pessoas em combater o racismo. (ALMEIDA, 2019).

${ }^{5}$ Produto do patriarcado que promove a socialização de homens e mulheres baseado na exploração, opressão, discriminação e machismo. (hooks, 2018). A nota se refere a escritos de Gloria Jean Watkins que utiliza o pseudônimo bell hooks inspirado na bisavó materna, Bell Blair Hooks, em homenagem as mulheres fortes. Utiliza a grafia bell hooks, em minúsculo, propondo um deslocamento da figura autoral para suas ideias.
} 
Educação e vivências interculturais: contribuições dos círculos de cultura em práticas libertadoras

I. A civilização moderna autodescreve-se como mais desenvolvida e superior (o que significa sustentar inconscientemente uma posição eurocêntrica).

2. A superioridade obriga a desenvolver os mais primitivos, bárbaros, rudes, como exigência moral.

3. O caminho de tal processo educativo de desenvolvimento deve ser aquele seguido pela Europa (é, de fato, um desenvolvimento unilinear e à europeia o que determina, novamente de modo inconsciente, a "falácia desenvolvimentista").

4. Como o bárbaro se opõe ao processo civilizador, a práxis moderna deve exercer em último caso a violência, se necessário for, para destruir os obstáculos dessa modernização (a guerra justa colonial).

5. Esta dominação produz vítimas (de muitas e variadas maneiras), violência que é interpretada como um ato inevitável, e com o sentido quase-ritual de sacrifício; o herói civilizador reveste a suas próprias vítimas da condição de serem holocaustos de um sacrifício salvador (o índio colonizado, o escravo africano, a mulher, a destruição ecológica, etcetera).

6. Para o moderno, o bárbaro tem uma "culpa" (por opor-se ao processo civilizador) que permite à "Modernidade" apresentar-se não apenas como inocente, mas como "emancipadora" dessa "culpa" de suas próprias vítimas.

7. Por último, e pelo caráter "civilizatório" da "Modernidade", interpretam-se como inevitáveis os sofrimentos ou sacrifícios (os custos) da "modernização" dos outros povos "atrasados" (imaturos), das outras raças escravizáveis, do outro sexo por ser frágil, etcetera.

A longa citação acima ilustra a complexa tarefa de educar rompendo com a lógica desumanizadora do capital. Educar para além do "paradigma” ocidental-moderno, alargando horizontes interpretativos, revendo memórias, descolonizando, fazendo do caminhar uma constante mirada para nós mesmos e os diversos modos de pensar, compreender e intervir na realidade, sem sacralizar esta ou aquela cultura, mas exercitando deslocamentos intersubjetivos, interculturais para, assim, gestar mudanças que realmente sejam estruturais.

É neste horizonte utópico-crítico que se insere este trabalho, na área de educação na Região do Contestado6, que ainda vive os impactos de séculos de colonialismo, imperialismo, violência e globalização do capital, mas que, também, é constituída de histórias, de experiências, de memórias e de resistências. Desde o território, procuramos criar espaços de diálogo sobre educação, filosofia e cultura; discutir com comunidades escolares e em outros espaços, temáticas acerca da formação docente e políticas educacionais; promover o exercício de aprendizagens colaborativas na forma de Círculos de Cultura comprometidas com práticas educativas transformadoras, como espaços de conhecimento, comunicação e reconhecimento de insuficiências culturais.

\footnotetext{
${ }^{6}$ O Território do Contestado está localizado em áreas de fronteira entre os Estados de Santa Catarina e Paraná, na Região Sul do Brasil, e leva este nome em referência à Guerra do Contestado (1912-1916). Conforme Fraga (20I2), a região do Contestado ainda vivencia a ausência de políticas públicas que rompam com o ciclo da desigualdade e da injustiça social.
}

Olhar de professor, Ponta Grossa, v. 24, p. I-27, e-16773.018, 2021.

Disponível em <https://revistas2.uepg.br/index.php/olhardeprofessor> 
Estas iniciativas revisitam a Pedagogia Libertadora de Paulo Freire e a coloca em diálogo com a Filosofia Intercultural, por meio de ações de extensão ${ }^{7}$ e de pesquisa ${ }^{8}$ que procuram vivenciar a teoria da ação dialógica (FREIRE, 1987; 1999a; 1999b; 2002; 2010), como exercício de transformação intercultural da filosofia entendida como saber contextual de pensamento e modo de vida (FORNETBETANCOURT, 200I; 2004).

A práxis em Círculos de Cultura (FREIRE, 1987; 2002) é aqui assumida como espaço de constituição de comunidades pedagógicas (hooks, 2013) e potencializada como centro de vivências interculturais em contraponto à educação bancária, que após cinco décadas da primeira edição da Pedagogia do Oprimido (FREIRE, 1987), segue atual na manutenção de sujeitos subalternizados, aniquilados da possibilidade de ser (FANON, 2005).

"Círculos de Cultura" são aqui tomados como exercícios de reterritorialização, de voltar-se para si, desde o território e de reconhecer-se em relação ao global e ao local. São espaços de tessitura de elos entre extensão e pesquisa universitária, portanto, no espaço acadêmico herdeiro da tradição colonial de produção-reprodução de conhecimentos de modo compartimentado, procuramos atuar concretamente no instituído. Ou seja, outras formas de fazer pesquisa e extensão na área de educação são aqui vivenciadas, propiciando a partilha de saberes e de experiências desde o território, numa polifonia de vozes, de possibilidades de pensar e estar no mundo.

Como resultados provisórios, foi possível perceber que princípios éticos, políticos e epistemológicos da dialogicidade e da construção coletiva do conhecimento presentes no legado freiriano podem ser fonte de inspiração para a transformação intercultural da filosofia como pensamento liberto e nos convocam a seguir na construção de iniciativas em prol de pensamentos descolonizados, humanizando-nos mutuamente.

\section{Educação e escolarização: campos de disputas}

A educação na América Latina, desde a colonização, cumpre uma função aniquiladora, de sobreposição da cultura burguesa contra a cultura popular, e sua institucionalização, por meio de

\footnotetext{
${ }^{7}$ Projeto de Extensão: A formação com professores de escolas públicas no município de União da Vitória/PR: tessituras nas ações de extensão e pesquisa para a formação profissional e ações junto à comunidade pedagógica no território local/regional (UNESPAR).

8 Projetos de Pesquisa: a) Tecendo convergências na construção de inéditos viáveis: Paulo Freire, interculturalidade e descolonização (estágio de pós-doutorado, PPGE/UFPR). b) Revisitando Paulo Freire: diálogos interculturais e práticas curriculares libertadoras (UNESPAR). c) Revisitando conceitos, concepções de políticas educacionais e as dimensões da pobreza no Brasil na atualidade: diálogos formativos com professores de escolas públicas dos municípios de União da Vitória/PR e Porto União/SC (UNESPAR).
} 
Educação e vivências interculturais: contribuições dos círculos de cultura em práticas libertadoras

escolas e universidades, vincula-se ao modelo ocidental transplantado e reinventado sob múltiplas influências, tais como a jesuíta, a francesa, a alemã e mesmo a norte-americana.

Com relação à universidade, Álvaro Vieira Pinto, em 196I, publica, pela União Nacional dos Estudantes (UNE), “A Questão da Universidade”, onde denuncia o elitismo, o conservadorismo e a dependedência cultural das estruturas universitárias em relação às elites econômicas no Brasil (VIEIRA PINTO, 1994), e em “A Universidade Necessária”, Darcy Ribeiro (1975) faz a defesa desta instituição como lócus de formação do intelectual público, como difusora e produtora de conhecimentos em sintonia com os desafios históricos e sociais do país. Em grande medida, ainda hoje "a questão da universidade" e "a universidade necessária" são temas que precisam ser revisitados, questão mais ampla que o escopo deste artigo que trazemos aqui para situar brevemente um dos territórios de nossas tessituras, a universidade.

Apesar do tripé ensino, pesquisa e extensão ser um princípio de qualidade e lócus de definição, tal como disposto no artigo 207 da Constituição Brasileira de 1988, de que "as universidades obedecerão ao princípio da indissociabilidade entre ensino, pesquisa e extensão" (BRASIL, 1988), no cotidiano, salvo algumas exceções, ainda há a compartimentalização e hierarquização entre estas funções da universidade. Certamente, são inúmeros os fatores que dificultam o exercício concreto desta indissociabilidade e entendemos que não abrir mão deste princípio é fundamental na constante reafirmação desta instituição em relação à efetivação de uma sociedade justa e democrática.

Como um dos fatores que dificultam o exercício da indissociabilidade entre ensino, pesquisa e extensão, localizamos a concepção de ciência ocidental reproduzida com base em noções de neutralidade, de validação de modos de argumentação e normatização do que e do que não seria conhecimento. Nesta perspectiva, por exemplo, quem ensina "transmite", quiçá didaticamente, seletivamente "conteúdos" da ciência de referência e a extensão ainda ocupa um espaço marginal, apesar de significativos avanços no período mais recente, como a inclusão da Meta 12.7 na Lei $n^{\circ}$ 13.005/20I4 que aprova o Plano Nacional de Educação (20|4-2024) (BRASIL, 20I4) e a aprovação das Diretrizes para a Extensão na Educação Superior Brasileira, Resolução № 7, de 18 de dezembro de 2018 (BRASIL, 2018)9.

Ainda quanto à extensão universitária, localizamos em Paulo Freire, na década de 1960, iniciativas pioneiras, conforme destaca Costa (2016, p. 48):

Paulo Freire teve, desde o início de seu trabalho como educador, uma relação muito próxima com a universidade. Apesar de às vezes ser considerado heterodoxo pela academia, percebe-se na sua atuação como educador (e como acadêmico) uma busca por usar os recursos conferidos por esta instituição para criar condições reais de

9 Disponível em: http://portal.mec.gov.br/index.php?option=com_docman\&view=download\&alias $=10425 \mathrm{I}$ rces007-I8\&category_slug=dezembro-2018-pdf\&Itemid=30192. Acesso em 10/08/2020.

Olhar de professor, Ponta Grossa, v. 24, p. I-27, e-16773.018, 2021.

Disponível em <https://revistas2.uepg.br/index.php/olhardeprofessor> 
alargamento de suas estruturas, a fim de permitir uma participação ativa e questionadora de pessoas sistematicamente marginalizadas de seus espaços. Talvez uma das experiências onde mais isso ficou evidente tenha sido seu trabalho como criador e coordenador do Serviço de Extensão Cultural em 1961, na Universidade de Recife, "a primeira experiência de extensão universitária do Brasil” (VERAS; MENDONÇA, 2009, p. 14-I5).

Desde suas primeiras atividades como educador, Paulo Freire se posicionou e interveio sem dicotomizar ensino, pesquisa e extensão, por exemplo, por meio da promoção de Círculos de Cultura. Atento ao paradigma hegemônico de produção e reprodução de conhecimentos e sua vinculação com as transformações econômicas, políticas e formas de sociabilidades nos marcos da cultura produziu desde a prática sua vasta obra, ocupando espaços em prol da formação pedagógica, que é política e cultural.

A racionalidade como expressão de pensamentos sob a égide da "racionalidade instrumental" (ADORNO; HORKHEIMER, 1986) torna cada vez mais rigorosa a necessidade de distanciamento do objeto, buscando-se neutralidade e imparcialidade como garantia de objetividade. Estas dicotomias na área da educação se expressam, por exemplo, por meio da concepção de ensino baseada na transmissão e memorização. Ao longo de seus escritos, Paulo Freire expressa sua concepção de conhecimento, ensino e pesquisa, tal como em Pedagogia da Esperança (FREIRE, 1999a, p. 192-193):

No fundo, a Universidade tem de girar em torno de duas preocupações fundamentais, de que se derivam outras e que têm a ver com o ciclo do conhecimento. Este, por sua vez, tem apenas dois momentos que se relacionam permanentemente: um é o momento em que conhecemos o conhecimento existente, produzido; outro, o em que produzimos o novo conhecimento. Ainda que se insista na impossibilidade de separarmos mecanicamente um momento do outro, ainda que se enfatize que são momentos de um mesmo ciclo, me parece importante salientar que o momento em que conhecemos o conhecimento existente é o preponderante o da docência, o de ensinar e aprender conteúdos e o outro, o da produção do novo conhecimento, é preponderantemente o da pesquisa. $\mathrm{Na}$ verdade, porém, toda docência implica pesquisa e toda pesquisa implica docência. Não há docência verdadeira em cujo processo não se encontre a pesquisa como pergunta, como indagação, como curiosidade, criatividade, assim como não há pesquisa em cujo andamento necessariamente não se aprenda porque se conhece e não se ensine porque se aprende. O papel da Universidade, seja progressista ou conservadora, é viver, com seriedade, os momentos deste ciclo. É ensinar, é formar, é pesquisar.

Em Pedagogia da Autonomia, ao tratar de saberes necessários à prática docente, expõe:

Não existe ensino sem pesquisa e pesquisa sem ensino. Esses que-fazeres se encontram um no corpo do outro. Enquanto ensino continuo buscando, reprocurando. Ensino porque busco, porque indaguei, porque indago e me indago. Pesquiso para constatar, constatando, intervenho, intervindo educo e me educo. Pesquiso para conhecer o que ainda não conheço e comunicar ou anunciar a novidade (FREIRE, 1999b, p. 32). 
Educação e vivências interculturais: contribuições dos círculos de cultura em práticas libertadoras

A concepção freiriana de conhecimento compõe sua teoria da ação dialógica para a construção da pedagogia libertadora. Seu horizonte é de ruptura com o modelo educativo historicamente construído, que divorcia pensamento, conhecer e vida. O controle sobre o que conhecer e quem é o sujeito de conhecimento tem papel central na estruturação do Estado, na medida em que assume o papel de formação de indivíduos a serviço da sociedade capitalista, o que leva à homogeneização e desestruturação de laços de solidariedade em nome da competitividade. Como dizia Gramsci (1982), as instituições escolares e universitárias são centro de formação intelectual, atuam na construção e reprodução de concepções de mundo.

No que tange à hegemonia como processo de direção intelectual e moral de uma classe sobre a outra, não há direção política sem estratégias e construção de consenso, e uma das formas de a burguesia assegurar sua manutenção no poder foi a utilização dos aparelhos privados de hegemonia, tais como a Escola e Universidades, com o objetivo de fabricar concepções de mundo, consensos e disseminar os valores e interesses do capital. Gramsci refere-se ao conceito de consenso como uma adesão "[...] espontânea dada pelas grandes massas da população à orientação impressa pelo grupo fundamental dominante à vida social, consenso que nasce 'historicamente' do prestígio (e, portanto, confiança) que o grupo dominante obtém, por causa de sua posição e de sua função no mundo da produção" (GRAMSCl, 1982, p. II).

A fabricação de consensos como forma de dominação e controle expressa uma larga estratégia de colonizar o outro. A lógica de funcionamento do Estado brasileiro e sua relação com as burguesias nacionais e internacionais passa pelo papel dos aparelhos privados de hegemonia como instrumentos do capital para a difusão de ideologia e a manutenção da hegemonia burguesa. No Brasil, projetos e políticas implementadas e em expansão não derivam somente de imposições unilaterais, mas resultam também de um pacto entre estados e frações do capital, nacional e internacional. Leher (2010, p. 372) aponta que as políticas dos governos possuem identidade própria. Os organismos multilaterais ou as relações intergovernamentais não tomam medidas impositivas aos governos. As agendas dos organismos, intelectuais coletivos do capital, são disseminadas massivamente pela própria burguesia local, nesse caso, recontextualizadas de acordo com as dimensões históricas, políticas, econômicas e culturais locais.

Sendo escolas e universidades herdeiras do projeto da modernidade ocidental-europeia, atuar nestes espaços em favor da humanização demandaria reinventá-los sob as bases de outras racionalidades, historicamente negadas, e gestando racionalidades transformadas, promovendo justiça cognitiva. Diante da dimensão macro política do capital, buscamos compreender o processo das políticas educacionais como um campo de disputas (DOURADO, 2015), uma vez que as políticas educacionais são pensadas e impostas às instituições formadoras, considerando as demandas e projetos

Olhar de professor, Ponta Grossa, v. 24, p. I-27, e-16773.018, 2021.

Disponível em <https://revistas2.uepg.br/index.php/olhardeprofessor> 
das organizações e organismos internacionais. Dourado (2015, p. 304) ressalta que "[...] a formação de profissionais do magistério da educação básica tem se constituído em campo de disputas de concepções, dinâmicas, políticas, currículos".

Este campo de disputa coloca grandes desafios aos intelectuais que desempenham funções no campo da educação, tais como as instituições formadoras de futuros docentes. A negação das diversidades, via escolas e universidades, está no centro dos interesses do capital e do mundo globalizado, pois assim gesta-se o ethos do mercado, destroem-se identidades, desterritorializam as pessoas e se reduzem as possibilidades de afirmação crítica da cultura, da política e da sociedade como um todo. A educação, nos marcos do capital, serve para dar coerência e um corpo cultural colonial ou neocolonial, quando aplicada às culturas diferentes, de forma homogeneizadora, aniquila o outro e as diversidades.

Além da crítica ao caráter alienante da educação, como espaço da reprodução, situamos algumas reflexões na perspectiva do entrelaçamento entre educação, política e cultura. A educação assim é concebida como território dinâmico, de resistências e de criação, de construção de modos de pensar a si no mundo em oposição ao capital e sua dinâmica de colonialidade do ser, do saber e do poder (QUIJANO, 2005, p. 227-278).

A colonização, segundo Quijano, dá início à colonialidade, construindo mentalidades pautadas na noção de inferioridades entre povos e culturas. Essa noção penetrou nas diversas práticas sociais ao longo do tempo, gestando a outra face da modernidade, tal como explicitado por Dussel. A colonialidade diz respeito a histórias, formas de vida, saberes e subjetividades colonizadas, a partir dos quais podem surgir respostas descoloniais. A perspectiva de superioridade/inferioridade, além de estar na base do conceito de superioridade étnica, também implica a superioridade epistêmica. $O$ conhecimento produzido pelo homem europeu, branco, é geralmente qualificado como científico, objetivo e racional, verdadeiro, enquanto aquele produzido por homens de cor ou por mulheres visto como mágico, subjetivo e irracional. Sob essa matriz epistemológica colonial, a historiografia, as filosofias e outras formas de conhecimentos oficiais têm desconsiderado inúmeras formas de manifestações culturais, sociais e políticas.

A colonialidade baseia-se na imposição de todo um sistema de classificação hierárquica de conhecimentos, territórios, indivíduos e culturas. A negação do outro é como parte constitutiva na efetivação da colonialidade, neste sentido, outros se tornam invisíveis ou são silenciados. A colonialidade epistêmica ou do saber não apenas estabelece o eurocentrismo como perspectiva única de conhecimento, mas também descarta as outras formas de vida e de produção intelectual.

Ao campo das teorias críticas, como o marxismo, os estudos pós-coloniais, descoloniais, o giro decolonial, as filosofias da libertação e a filosofia intercultural procuram chamar atenção para a 
Educação e vivências interculturais: contribuições dos círculos de cultura em práticas libertadoras

necessidade de rupturas mais radicais com o paradigma moderno-ocidental, projeto a se construir ampliando-se o mapa-mundi do pensamento, alargando os horizontes para acolher a construção de outras narrativas desde as vozes silenciadas. Trata-se da viabilização de experiências que incidam na discursividade da história enunciando possibilidades outras de ser e estar no mundo e que, no campo educacional, implica em outra pedagogia, anticolonial, libertadora, intercultural, sob as bases de racionalidades transfiguradas (FORNET-BETANCOURT, 200I), contra o iluminismo pedagógico e cultural que acentua a aquisição de conhecimentos em nome de uma universalidade abstrata, que nega a mundialidade concreta (DUSSEL, 2005, p. 63).

A colonialidade se faz na constituição de sujeitos colonizados, que, em última análise, significa a constituição do pensamento, seus modos de compreender e se relacionar com a vida. As ações educativas que se pretendem libertadoras implicam-se na contraposição às formas de relações de poder colonial, na crítica e na autocrítica de reconhecimento de insuficiências ético-políticas-estéticas e epistêmicas.

\section{Paulo Freire revisitado e um enlace intercultural}

Vivendo no exílio em 1968, o brasileiro mundialmente conhecido Paulo Freire publicou Pedagogia do Oprimido, obra central em sua vasta produção, na qual denuncia o modelo de educação antidialógico, educação bancária, a serviço da manutenção do status quo, e anuncia a possibilidade da educação como libertação, dialógica e comprometida com a transformação da sociedade. As primeiras palavras da obra nos revelam sua atualidade:

Mais uma vez os homens, desafiados pela dramaticidade da hora atual, se propõem a si mesmos como problema. Descobrem que pouco sabem de si, de seu "posto no cosmos", e se inquietam por saber mais. Estará, aliás, no reconhecimento do seu pouco saber de si uma das razões desta procura. Ao se instalarem em quase, senão trágica descoberta do seu pouco saber de si, se fazem problema a eles mesmos. Indagam. Respondem, e suas respostas os levam a novas perguntas. O problema de sua desumanização, apesar de sempre dever haver sido, de um ponto de vista axiológico, o seu problema central, assume hoje, caráter de preocupação iniludível (FREIRE, 1987, p. 29).

O autor é um dos intelectuais latino-americanos que problematizou a dimensão colonial e a aborda como prática histórica de opressão, portanto, de desumanização. A desumanização, entendida como "o resultado de uma ordem injusta que gera a violência dos opressores, o que, por outro lado, desumaniza os oprimidos", é uma distorção da vocação ontológica de ser mais. Enfrentar esse problema é reconhecer a necessidade de restauração da humanidade, da criação de estruturas sociais e educativas que equipem os oprimidos com ferramentas necessárias para (des)velar as raízes da 
opressão e desumanização, identificando suas estruturas e atuando sobre elas (FREIRE, 1987, p. 7475).

Em Pedagogia da Esperança, ele retoma o tema humanização-desumanização como devir humano e da necessária "ruptura das amarras reais, concretas, de ordem econômica, política, social, ideológica etc., que nos estão condenando à desumanização" (FREIRE, 1999a, p. 99), e a dialética entre o conhecimento e a transformação da realidade como distintos, mas conectados.

Dessa forma, a filosofia da educação como libertação iniciada por Freire conseguiu, de um lado, desmistificar os sonhos do pedagogismo dos anos 60, que, pelo menos na América Latina, sustentava a tese de que a escola tudo podia, e, de outro lado, conseguiu superar o pessimismo dos anos 70, para o qual a escola era meramente reprodutora do status quo. Fazendo isso - superando o pedagogismo ingênuo e o pessimismo negativista - conseguiu manter-se fiel à utopia, sonhando sonhos possíveis. Fazer hoje o possível de hoje para amanhã fazer o impossível de hoje (GADOTTI, 1997). Denuncia saberes e práticas epistêmicas colonizadoras e anuncia uma proposta contra hegemônica, de percepção e criação de "inéditos viáveis" como caminho de superação de "situações-limites", situações de desesperança 10 .

“Inéditos viáveis" é busca de realização da vocação ontológica de ser mais, exercício de perceber mais além, que em última análise é afirmação do direito ao pensar autenticamente, centro da educação problematizadora, de diálogo sobre visões de mundo e sobre "situações limites" (FREIRE, 1987, p. 6I, 72, 87, 94 e 107).

Em meio à capacidade global de desumanização, de inúmeras "situações limites", a filosofia intercultural propõe uma reorientação do pensar. Uma reorientação hermenêutica, ética e política, um exercício de reconhecimento da pluralidade cultural e cognitiva, como uma: "exigencia normativa que brota de la realidad misma de nuestra situación histórica, y del reto de la convivencia solidaria en una humanidad diseñada por diferencias singulares e insustituibles" (FORNET-BETANCOURT, 2006, P. 51$)^{\prime \prime}$.

Em Interculturalidade: críticas, diálogo e perspectivas, Fornet-Betancourt (2004, p. 13) expõe o que compreende por interculturalidade:

\footnotetext{
10 "Inéditos viáveis" é uma expressão cunhada por Paulo Freire para se referir ao futuro a ser construído desde o cotidiano como resistência e criação. O problema das "situações-limites" utiliza, a partir do filósofo brasileiro Álvaro Vieira Pinto, que, esvaziando a dimensão pessimista do termo presente em Jarpers, o redimensiona: não são "o contorno infranqueável onde terminam as possibilidades, mas a margem real onde começam todas as possibilidades"; não são "a fronteira entre o ser e o nada, mas a fronteira entre o ser o ser mais" (mais ser) (VIEIRA PINTO, 1960, p.284; FREIRE, 1987, p. 90). Ver também Pedagogia da Esperança (FREIRE, 1999, p. II, 205-207).

"Tradução dos autores: "exigência normativa que surge da mesma realidade de nossa situação histórica, e do desafio da convivência solidária em uma humanidade desenhada por diferenças singulares e insubstituíveis" (FORNET-BETANCOURT, 2006, p. 5I).
} 
[...] por interculturalidade compreende-se aqui não uma posição teórica, nem tampouco um diálogo de/e/ou entre culturas [...] senão que interculturalidade quer designar, antes, aquela postura ou disposição pela qual o ser humano se capacita para, e se habitua a viver "suas" referências identitárias em relação com os chamados "outros", que dizer, compartindo-as em convivência com eles. Daí que se trata de uma atitude que abre o ser humano e o impulsiona a um processo de reaprendizagem e recolocação cultural e contextual. É uma atitude que, por nos tirar de nossas seguranças teóricas e práticas, permite-nos perceber o analfabetismo cultural do qual nos fazemos culpáveis quando cremos que basta uma cultura, a "própria”, para ler e interpretar o mundo.

A filosofia intercultural posiciona-se diante do contexto atual, com o objetivo de contribuir na construção de alternativas frente à globalização mundial em diálogo com a tradição de pensamento latino-americano e demais teorias críticas, como o marxismo, a teoria da ação comunicativa e as filosofias da libertação, aponta uma limitação comum, não superam o âmbito de sua cultura:

Porque todas estas corrientes representan ciertamente profundas transformaciones de la filosofía, pero adolecen no obstante de una limitación común y es que son trans-formaciones de la filosofía que no superan el horizonte de su cultura o ámbito cultural correspondiente. Son, si se quiere, transformaciones monoculturales de la filosofía; mientras que ahora nos encontramos en una situación histórica e intelectual que parece pedir una transformación de la filosofía más radical que la que pudiese ser llevada a cabo recurriendo al material crítico de una determinada tradición cultural. Esta nueva constelación de saberes y culturas, es para nosotros precisamente la trans- formación intercultural; $y$ entendemos por ello el programa de crear una nueva figura de la filosofía (FORNET-BETANCOURT, 200I, p. I8). ${ }^{12}$

A filosofia, compreendida não apenas como disciplina acadêmica ou atividade profissionalizada, precisa "abrir-se" ao exercício intercultural, e como filosofia intercultural se insere na "trincheira das ideias"; no campo da produção de saberes e conhecimentos correlacionados como ferramenta de luta; de convocação ao reconhecimento da pluralidade de visões de mundo e da diversidade cultural como exigência ético-política, pois as culturas expressam a situação de condicionamentos, de práxis de libertação ou de dominação.

Embora a ideia de interculturalidade não estivesse presente nas conceituações de Paulo Freire, o tema das diversidades permeiam sua teoria da ação dialógica. Sua concepção de educação, como ação cultural de libertação, reconhece as diversidades culturais, os contextos de vida, as condições existenciais, línguas e culturas diversas, de tal modo que arriscamos afirmar que sua pedagogia

\footnotetext{
${ }^{12}$ Tradução dos autores: "Porque todas essas correntes representam certamente transformações profundas da filosofia, mas sofrem, no entanto, de uma limitação comum: são transformações da filosofia que não ultrapassam o horizonte de sua cultura ou esfera cultural correspondente. São, se desejado, transformações monoculturais da filosofia; ao passo que agora nos encontramos em uma situação histórica e intelectual que parece exigir uma transformação mais radical da filosofia do que aquela que poderia ser realizada recorrendo a material crítico de uma dada tradição cultural. Esta nova constelação de conhecimentos e culturas é para nós precisamente a transformação intercultural; e por isso entendemos o programa de criação de uma nova figura da filosofia" (FORNET-BETANCOURT, 200I, p. I8).
} 
libertadora é um fato intercultural. A valorização das diversidades culturais se insere em sua crítica ao modelo de Estado-moderno, Estado-nação, como pode ser conferida no livro em diálogo, Por uma Pedagogia da Pergunta:

[...] ○ Estado-moderno, enquanto Estado-nação, conforma-se com a exigência autoritária de um grupo da sociedade que impõe unidade à nação, reduzindo, eliminando as diferenças culturais que podiam existir nessa Nação-estado ou nesse Estado-nação. Penso que, desde a formação do Estado moderno persiste essa tendência de alcançar a unidade por meio da anulação da diversidade [...]. Eu diria que esse caminho seguido até este momento é um caminho errado, porque anulou as diversidades que poderiam enriquecer a unidade (FAUNDEZ; FREIRE, 1985, p. 86).

O problema do encobrimento da diversidade cultural no paradigma modernizante de mundo, como já apontado aqui, situa-se na concepção de sujeito abstrato, que nega as diferenças. Freire (1987, p. 37; 2010, p. 75) expressa uma reformulação gnosiológica para a superação do idealismo, a noção de sujeito solipcista anunciador de "verdades" e quanto a superação objetivista mecanicista que inviabiliza o papel dos seres humanos na transformação de si e da realidade e "a relação dialógica é o selo do processo gnosiolológico (FREIRE, 2012, P. I3I).

Quanto à filosofia do sujeito, Fornet-Betancourt (200I) expõe que, contemporaneamente, pensadores como Deleuze, Derrida, Foucault e a antropologia de Lévi-Strauss produziram importantes críticas ao conceito moderno de sujeito, que não só representa uma ilusão como tem contribuído para consequências totalitárias. Destaca a relevância da superação da concepção de humanismo egocêntrico e o caminhar criativamente na perspectiva do humanismo ético-crítico, de modo que possamos buscar a construção de subjetividades que contribuam na superação da globalização neoliberal, que nada mais é que $\circ$ acirramento dos princípios da modernidade implantada, desde Descartes (FORNETBETANCOURT, 200I).

A superação da concepção de sujeito autocentrado, egocêntrico destaca a importância de um movimento transformador rumo ao pensar respectivo, que não uniformize vozes e não as reduzam a práticas monoculturais. Este pensar respectivo proposto inspira-se em Xavier Zubiril3 como busca de compreensão em que o pensamento, a inteligência, são exercidos de forma aberta ao real e a cultura:

No ejercite la inteligencia para cerrar en un sistema el curso de la realidad, sino que la entienda como respuesta sentiente a la apertura fundacional que constituye todo lo real como algo que es respectivo a... Respectividad, como formal apertura de lo real, indicaría así la necesidad de afirmar la interna relación del modo de realidad en el que se está - pongamos aquí el caso de la cultura propia - con los otros modos

\footnotetext{
${ }^{13}$ Filósofo espanhol Xavier Zubiri (1898-1983). Zubiri elabora questionamentos a conceitos clássicos da filosofia ocidental e formula uma nova concepção de inteligência e de realidade. A filosofia clássica, para ele, "substantivou" e "entificou" a realidade, ao mesmo tempo em que "logificava" a intelecção, frente a isso Zubiri propõe outra noção de logos, a partir da noção de inteligência senciente (FORNET-BETANCOURT, 200I, p. 32).
} 
Educação e vivências interculturais: contribuições dos círculos de cultura em práticas libertadoras de realidad (FORNET-BETANCOURT, 200I, p. 32). ${ }^{14}$

O pensamento respectivo resulta num movimento que visa superar o relativismo, assegurando uma apreensão não totalitária do real e situando-se como pensar relacional, rompendo com a noção de inteligência fechada em si mesma e da realidade como "representação". Fornet-Betancourt pontua que se inspira neste conceito zubiriano, mas não o emprega no sentido metafísico como o autor espanhol e sim para fundar um movimento dialético-dialógico de comunicação e compreensão livre, de reciprocidade entre todos os sujeitos, compartilhando a palavra com outras palavras, aprendendo a compreender, a apresentar a própria palavra como sempre respectiva à outra (FORNETBETANCOURT, 200I, p. 68-69).

Trata-se de uma busca de referenciais teóricos para a formação da existência humana enquanto subjetividade participativa, aberta, inacabada, de qualificação de si mesma:

[...] existencia que se sabe como siendo ya en relación con outro o, más exactamente, que es conciencia (de si) como conciencia de y entre los otros; y que, por tanto, su subjetividade "interesada" (inter-esse) em y por el outro, no puede lograr dicha calidad si no como formación ética (FORNET-BETANCOURT, 200I p. $217-218) .15$

Tal sentido nos remete ao pensamento de Paulo Freire, em sua compreensão ético-crítica libertadora. Freire insere numa síntese inovadora de diferentes correntes do pensamento filosófico crítico contemporâneo, propondo caminhos de investigação dialógica do pensamento popular, com o objetivo de construção de um processo educativo libertador. Trata-se, portanto, de uma subjetividade interessada na construção do conhecimento que se dê na ação e na comunicação, partindo de "situações" concretas, refletindo sobre seu modo de estar no mundo e, então, indo além da situacionalidade.

Ao abordar o processo de formação da consciência crítica, por meio da educação como ação cultural libertadora, Freire explicita uma ontologia do ser mais e confronta falsas posições intelectuais, que considera intelectualista ou solipsista. Ele aposta na consciência crítica, que só pode existir na práxis, isto é, no processo ação-reflexão, consciência histórica, na qual o conhecimento é resultante de um processo dos seres humanos entre si e com a realidade, e mesmo a existência individual em

\footnotetext{
14 Tradução dos autores: "Não se deve exercitar a inteligência para fechar o curso da realidade em um sistema, mas entendê-la como uma resposta simples à abertura fundacional que constitui tudo o que é real como algo que é respectivo a ... Respectividade, como abertura formal do real, indicaria assim a necessidade de afirmar a relação interna do modo de realidade em que estamos - colocamos aqui o caso da própria cultura - com os outros modos de realidade" (FORNET-BETANCOURT, 200I, p. 32).

15 Tradução dos autores: "[...] existência que se sabe já estar em relação com o outro ou, mais exatamente, que é consciência (de si) como consciência de e entre os outros; e que, portanto, sua subjetividade "interessada" (inter-esse) no e pelo outro, não pode atingir essa qualidade senão como uma formação ética" (FORNETBETANCOURT, 2001 p. 217-2I8).
}

Olhar de professor, Ponta Grossa, v. 24, p. I-27, e-16773.018, 2021.

Disponível em <https://revistas2.uepg.br/index.php/olhardeprofessor> 
suas singularidades são expressões de formas sociais de existência. A práxis de libertação representada na categoria freiriana de dialogicidade é processo, ou seja, é permanente produção e comunicação de saberes, conhecimentos e experiências, tendo como fio condutor do exercício o educar-se mutuamente, o pensar com e não para:

Ninguém educa ninguém, ninguém educa a si mesmo, os homens se educam entre si, mediatizados pelo mundo. [...] ninguém educa ninguém, como tampouco ninguém se educa a si mesmo: os homens se educam em comunhão, mediatizados pelo mundo. Mediatizados pelos objetos cognoscíveis [...] (FREIRE, 1987, p. 68 e p.79).

[...] não posso pensar pelos outros nem para os outros, nem sem os outros. A investigação do pensar do povo não pode ser feita sem o povo, mas com ele, como sujeito de seu pensar. $E[\ldots]$ será pensando o seu pensar, na ação, que ele mesmo se superará. E a superação não se faz no ato de consumir ideias, mas no de produzi-las e de transformá-las na ação e na comunicação (FREIRE, 1987, p. I0I).

Então, o pensar com os outros, o pensar sobre o pensado, ou seja, sobre racionalidades que estruturam, condicionam o pensamento de cada época, está presente na teorização freiriana e revela uma intrínseca relação entre pensamento, linguagem e contexto social; entre o político e o cultural, a dialogicidade, portanto, se efetiva como ação cultural.

A imersão, a compreensão crítica da cultura, portanto, deveriam ser componentes do processo educativo, visto que, como destaca Fornet-Betancourt (200l), é na dialética entre determinação e liberdade, no seio da cultura que cada pessoa se constitui. Culturas dizem da produção humana e é sobre o humano que há contradições sociais, políticas, econômicas, éticas. São feitas de lutas internas, de conflitos em relação a tradições e interpretações de si mesmas, de permanentes processos de ressignificações. A tensão dialética entre opressão e libertação se dá no berço da cultura e cada pessoa é levada a situar-se diante se "sua" cultura, a discernir, identificar-se ou não com a mesma.

A cultura é aqui assumida como teia de significados, um entrelaçado sistema de significados, "[...] um sistema de concepções herdadas expressas em formas simbólicas por meio das quais os homens comunicam, perpetuam e desenvolvem seu conhecimento e suas atividades em relação à vida" (GEERTZ, 1989, p. 103).

Quanto à dialética opressão e libertação, Fornet-Betancourt (200I) nos lembra que foi analisada filosoficamente, tal como por Jean-Paul Sartre e sua filosofia da liberdade, e na pragmática transcendental de Karl-Otto Apel. O autor destaca que esta dialética opressão e libertação como articulação dos oprimidos, desde uma cultura, foi mais bem descrita e analisada na ética da libertação de Enrique Dussel, concretizando uma práxis ético-crítica com imperativo de liberar as vítimas:

[...] la ética de Dussel parece ofrecer, en efecto, la mejor clave para interpretar los conflictos internos que fragmentan las culturas a este nivel. Es más, su ética ofrece también el norte necesario para optar ético-críticamente dentro de la "propia" cultura, comprometiéndose en su renovación y reorganización desde la óptica de la

Olhar de professor, Ponta Grossa, v. 24, p. I-27, e-16773.018, 2021.

Disponível em <https://revistas2.uepg.br/index.php/olhardeprofessor> 
Educação e vivências interculturais: contribuições dos círculos de cultura em práticas libertadoras memoria de liberación de las víctimas ${ }^{16}$ (FORNET-BETANCOURT, 200I, p. I40$14 \mid)^{17}$

Ao captar a dialética opressor e oprimido, com atenção especial aos mecanismos de interiorização da mentalidade colonizadora, atento a situação colonial (FANON, 2005), Freire construiu uma filosofia da educação apostando na libertação como paradigma. Destaca-se que isso se deu antes mesmo da ética da libertação de Enrique Dussel, portanto, a Pedagogia do Oprimido, publicada em 1968, inaugura esta perspectiva.

A construção de processos educativos são exercícios de socialização de bens materiais e simbólicos, portanto, a educação intercultural e libertadora passa pela discussão de que bens serão socializados, que escolhas serão feitas sobre o que deve ou não ser compartilhado, sem participação ativa de todos/as, ou seja, sem a radicalização da vivência democrática não há educação para libertação.

A dialogicidade é um caminho para rupturas com posições elitistas, de busca de compreensão e aprendizado acerca das estruturas de pensamento, dos jeitos, formas de conhecer e de comunicar. Para que se fortaleçam as funções libertadoras, que são processos contínuos de humanização com o outro, é preciso responder às necessidades de cada cultura, entendida na dinâmica histórica de cada sociedade, sem pretensão de ser integradora, mas que de forma dialógica se faça intercultural.

\section{Círculos de cultura e vivências interculturais}

Freire propõe "Círculos de Cultura” por buscar uma organização horizontal entre os sujeitos, seus saberes e suas experiências. Trata-se de uma educação de novo modo didático-espacial-temporal:

[...] em lugar de escola, que nos parece um conceito, entre nós, demasiado carregado de passividade, em face de nossa própria formação (mesmo quando se lhe dá o atributo de ativa), contradizendo a dinâmica fase de transição, lançamos o Círculo de Cultura. Em lugar do professor, com tradições fortemente "doadoras", o Coordenador de Debates. Em lugar de aula discursiva, o diálogo. Em lugar de aluno, com tradições passivas, o participante de grupo. Em lugar dos pontos e de programas alienados, programação compacta, reduzida e codificada em unidades de aprendizado (FREIRE, 2002, p. III).

Quando Freire fala “cultura”, diz respeito a ações do cotidiano, ou seja, a cultura é exatamente o cotidiano das pessoas e seus modos concretos de estar no mundo. A circularidade nos remete à

\footnotetext{
${ }^{16}$ Cf. Enrique Dussel, Arquitectónica de una ética de la liberación en la Edad de la Globalización y la Exclusión, Madrid/México 1998; especialmente el capítulo 6.

17 Tradução dos autores: "[...] A ética de Dussel parece oferecer, com efeito, a melhor chave para interpretar os conflitos internos que fragmentam as culturas neste nível. Além disso, sua ética também oferece o norte necessário para escolher ética-criticamente dentro da "própria" cultura, comprometendo-se com sua renovação e reorganização na perspectiva da memória da libertação das vítimas” (FORNET-BETANCOURT, 200I, p. I40|4I).
}

Olhar de professor, Ponta Grossa, v. 24, p. I-27, e-16773.018, 2021.

Disponível em <https://revistas2.uepg.br/index.php/olhardeprofessor> 
possibilidade ininterrupta de que os conhecimentos circulem, dialoguem, se contraponham e que sempre recomecem outros estágios de permanente recomposição. Esta ideia dialética e dialógica de movimento propicia a compreensão de que práticas educativas não podem ser estáticas, porque o contexto histórico-social-cultural em que se vive, a todo momento, exige que novas posturas sejam tomadas frente à vida.

Paulo Freire trabalhou incansavelmente na construção de uma educação circular, libertadora, e deixou importantes pistas como possibilidades para essa construção, pistas a serem melhoradas e qualificadas, como ele mesmo dizia. Mas o fundamental está na crença do ser humano como inacabado, capaz de sínteses teóricas, mas consciente de que elas são provisórias.

Nas tessituras horizontais de saberes e conhecimentos, encontramos na compreensão de Freire sobre conhecimento, cultura e educação, um ponto de partida para o desenvolvimento de práticas educativas em círculos de cultura, nos quais aproximamos a pedagogia freiriana da filosofia intercultural. As iniciativas elencadas a seguir representam um esforço e dedicação coletiva de vivências concretas, em que pesquisa e extensão se efetivam em espaços de ensino e aprendizagens.

Nestes espaços, a interculturalidade tem sido referência no reconhecimento e acolhimento das diversidades, de confronto com o instituído (monocultural/bancário); de valorização das pessoas como sujeitos cognitivos; de exercício reflexivo e problematizador acerca do tempo histórico em que vivemos; de escuta e registro de narrativas memoriais (coletivas e individuais) num ciclo de autoaprendizado coletivo que procura fundar comunidades pedagógicas (hooks, 2013, p. 173-222). Desse modo, intensificando o exercício, ainda que experimental, do direito à palavra e do compartilhamento de sentidos, que, em última análise, representa um investimento na qualidade subjetiva como componente educativo, intercultural e libertador.

Provocando o encontro com o outro, temos criado espaços, tais como: a) Círculos de Cultura: "Leia Mulheres", que acontece desde 2017, em União da Vitória/PR (UNESPAR) e teve uma edição em Curitiba/PR, no ano de 2019 (NESEF/UFPR)18; b) Círculo de Cultura "Currículo e Território", na Escola Municipal Dario Bordin, em União da Vitória/PR; c) do Círculo de Cultura "Paulo Freire, Currículo e Território", no Colégio Estadual Izelina Daldin Gaiovicz, no município de General Carneiro/PR.

Com o objetivo de promover encontros de mulheres e dar visibilidade aos escritos de mulheres de distintos períodos históricos, de diferentes culturas e de distintas áreas de conhecimento,

\footnotetext{
${ }^{18}$ Círculo de Cultura Leia Mulheres, que ocorreu durante o ano de 2019, Programa de Pós-Graduação em Educação (PPGE), via Núcleo de Estudo e Pesquisas sobre Ensino de Filosofia (NESEF/UFPR), no âmbito do Estágio de Pós-doutoramento de uma das autoras deste artigo. Destacamos que esta iniciativa, juntamente com a realização do Ciclo de Estudos "Paulo Freire: interculturalidade e pedagogias descoloniais", procurou entrelaçar pesquisa, ensino e extensão.
}

Olhar de professor, Ponta Grossa, v. 24, p. I-27, e-16773.018, 2021.

Disponível em <https://revistas2.uepg.br/index.php/olhardeprofessor> 
Educação e vivências interculturais: contribuições dos círculos de cultura em práticas libertadoras

o "Círculo de Cultura Leia Mulheres", que nasceu no âmbito do Projeto de Extensão "TEAR: Tecendo Estudos e Ações em Rede pela Vida das Mulheres" (2017-2018) e hoje compõe as ações do Programa Coletivo Paulo Freire de Filosofia, Educação e Cultura, tem realizado a problematização, com a mediação de leituras de obras escritas por mulheres, acerca das relações de gênero, atuando na formação e na prevenção da violência contra mulheres.

A prática do Círculo de Cultura Leia Mulheres situa-se na valorização da sabedoria das mulheres, tal como nos lembra Menezes, ao citar Diana Vallescar:

A questão de gênero tem uma profunda relação com a interculturalidade. Como comenta Diana Vallescar, é preciso "recuperar as sabedorias e as experiências das mulheres procedentes de diferentes culturas e, ao mesmo tempo, a ideia de que puderam também operar como corretivo frente a determinadas afirmações e visões (impostas) por teorizações feministas". A filósofa comenta que existem aspectos comuns entre a análise de gênero e a interculturalidade. Destaca que ambas: I. denunciam a assimetria cultural; 2 . fazem a crítica a uma cultura dominante e sua superação; e, 3. buscam a luta e transformação das relações e mundos de vida (MENESES, 2015, p. 76-77).

Com encontros mensais, a escolha das leituras são tematizadas coletivamente e dialogicamente, e nesta construção são muitos os aprendizados, entre os quais: a) a descoberta de que é possível tecer saberes junto com outras mulheres; b) de que mulheres historicamente proibidas de ler e de escrever resistiram e escreveram, algumas chegaram até nossos dias, muito se perdeu e não temos conhecimento; c) de que não se trata apenas de visibilizar ou integrar as mulheres na filosofia ou demais áreas de conhecimento, mas ao dialogar com elas, seus escritos e experiências fazem filosofia e produzem conhecimentos de outro modo. Refundar, transformar, significa aceitar e insistir que as mulheres, por elas mesmas, digam de que maneira necessitam e desejam expressar suas próprias experiências, rompendo com preconceitos sexistas que as silenciam interessadamente.

Na figura I temos recorte de "mandalas" em tecido que foram produzidas pelas participantes, com registros de experiências, aprendizados, sentimentos e memórias. A escrita coletiva é um dos momentos da escuta das vozes das mulheres presentes no Círculo de Cultura, mas também simboliza as vozes das mulheres lidas com as quais estabelecemos diálogos interculturais e intergeracionais.

Olhar de professor, Ponta Grossa, v. 24, p. I-27, e-16773.018, 2021.

Disponível em <https://revistas2.uepg.br/index.php/olhardeprofessor> 
Figura I: Mandalas círculo de cultura Leia Mulheres

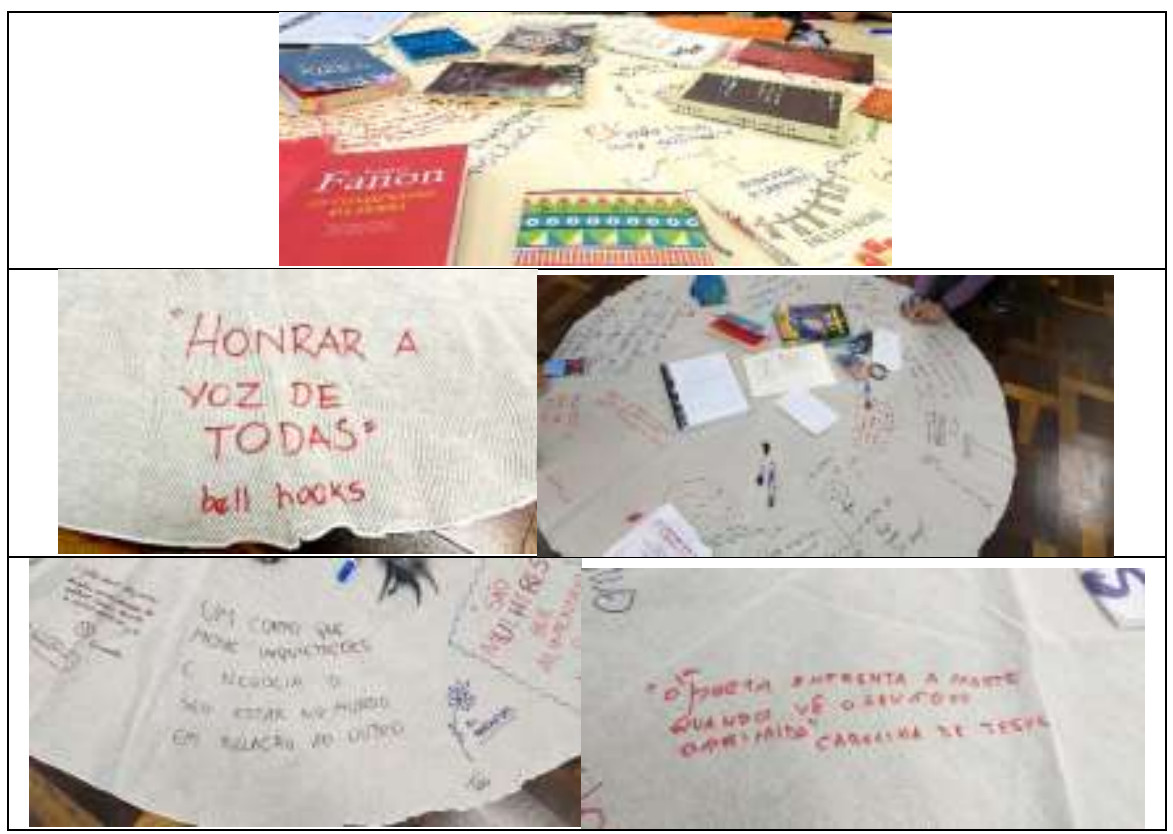

Fonte: Arquivo pessoal dos autores, 2019.

Círculos de Cultura possibilitam o desenvolvimento de ações que acolhem narrativas memoriais e histórias de vida, combatendo o analfabetismo cultural, biográfico e comunitário (FORNET-BETANCOURT, 2004) e a tematização destas narrativas em relação aos territórios objetivos e subjetivos, como expressa Menezes (20I5, p. 72-73):

É preciso recuperar o exercício de escutar sua própria voz, mais do ser escutada, é preciso se escutar. Escutar seus diferentes sons, escutar o corpo calado, o silêncio, que não é necessariamente emudecimento, as expressões, formas, jeitos de estar e sentir o mundo que não passam pela expressividade ditada no espaço público. $O$ direito a palavra é o direito de pronunciá-la em suas diferentes línguas, inclusive mesmo, como impossibilidade de compreensão.

A ampliação dos espaços democráticos ao máximo é condição para a conquista e manutenção de direitos e, entre os direitos, há que se discutir o direito à autodeterminação da diversidade dos povos, das culturas, do direito à diferença nos modos de ser e de se expressar. Trata-se, portanto, da formação de racionalidades interculturais, para a promoção da participação efetiva de todos no mosaico humano que nos constitui.

Adotamos como metodologia de trabalho convidar pessoas interessadas, estudantes, docentes, membros de comunidades onde se localizam as escolas e universidades, para juntos construirmos comunidades de aprendizagens (hooks, 2013) e o formato de Círculo de Cultura, ou não, é definido coletivamente. Trata-se de um exercício de reconstrução coletiva da história desde nosso território, de nossas memórias e experiências, de "abajo" e desde "el sur". 
Educação e vivências interculturais: contribuições dos círculos de cultura em práticas libertadoras

Cada comunidade pedagógica, na forma de círculos de cultura ou de ciclo de estudos, constrói seu programa de investigação-ação-participativa (FALS-BORDA, 20I5), desde suas especificidades, definidas democraticamente, circularmente tematizando, investigando e problematizando a realidade concreta de modo "conteúdos" formativos são retirados dos processos do diálogo comunitário.

O Círculo de Cultura "Paulo Freire, Currículo e Território", na Escola Estadual Izelina Daldin Gaiovicz, em General Carneiro/PR, teve como destaque as temáticas de educação, raça e pobreza, reconstruindo as identidades territoriais e étnico-raciais, para a definição e desdobramento dos temas geradores de estudo e ações do grupo.

A partir das narrativas biográficas e comunitárias das pessoas participantes, o tema gerador que surgiu foi "território" e o coletivo pôde construir uma outra geografia, uma outra cartografia, enfim, uma outra visão e uma outra compreensão dos territórios físico e social que habitam. Como investigação temática, cada pessoa trouxe fontes documentais, da memória oral sobre suas famílias, comunidades e município. No compartilhamento das investigações, foi possível revisitar a história oficial e revê-la criticamente quanto, por exemplo, ao apagamento da população negra na região, a presença nos dias atuais de trabalho análogo ao trabalho escravo, a concentração de terras e a destruição ambiental.

Neste contexto, concluímos que a iniciativa positiva do Círculo de Cultura, com reuniões aos finais de semana recheadas de afetividade, encontrou limites em inserir suas temáticas e concepção no currículo formal da escola, principalmente devido à pouca adesão de professores/as; por outro lado, com significativa participação de funcionárias da escola, equipe pedagógica e estudantes egressos.

O Grupo de Estudos "Pedagogias Insubmissas: interculturalidade, gênero, raça e pobreza”, na Universidade Estadual do Paraná (UNESPAR), campus de União da Vitória/PR, realizou encontros ao longo de 2019 e foi organizado a partir dos Projetos de Pesquisa e Extensão aqui citados. Destaca-se que a inciativa nasceu a pedido de estudantes de graduação em Química, Filosofia e Pedagogia, a partir do questionamento de estudarem pouco, nos seus currículos, as temáticas acima e autores como Paulo Freire, Frantz Fanon, Rául Fornet-Betancourt, entre outros.

O Círculo de Cultura na Escola Municipal Dário Bordin, em União da Vitória/PR, é composto pelos proponentes deste artigo e profissionais da Escola Dario Bordin, educadoras e educadores, coordenação pedagógica e direção. Integra ações de extensão, via Pró-Reitoria de Extensão e Cultura - PROEC/UNESPAR, para com a comunidade pedagógica, estruturado para continuidade a partir dos temas geradores e ações dialógicas em 2020. Esta ação também está vinculada ao Programa Coletivo Paulo Freire de Filosofia, Educação e Cultura (UNESPAR).

$\mathrm{Na}$ Figura 2, ilustramos brevemente algumas ações nas duas escolas da rede pública (municipal e estadual) onde também estamos desenvolvendo os círculos de cultura. É importante destacar que a 
educação é um campo em que se travam disputas políticas e de diferentes concepções a respeito do que é educar, ensinar e aprender. A ampliação de mecanismos de participação, de escuta e diálogo é condição para que essas diferenças sejam objeto de debate e de reflexão, assumindo a educação como processo. Não há democracia sem participação, não há participação sem diálogo e não há diálogo sem o acolhimento do outro em seu direito à palavra. Trata-se de não negar a politicidade inerente à educação, mas assumi-la buscando viver plenamente a opção política democrática e a prática educativa igualmente democrática.

Ao partir da realidade da comunidade, das suas especificidades históricas e culturais que partejaram identidades, lutas, sonhos, realizações e resistências, acreditamos ser possível estruturar um projeto educativo diferente; estabelecer conexões entre organização social comunitária e educação; entre desenvolvimento humano e educação; entre práticas culturais e educativas. Um diálogo vivo que evidencie a educação como direito vinculado a pretensões concretas.

Em nosso continente, a atividade intelectual ocorre fundamentalmente nas instituições universitárias, ou seja, sob as bases do colonialismo europeu, e os Círculos de Cultura, ao radicalizarem o exercício da democracia desde o modo como se ensina, se aprende, quem ensina, quem aprende e sobre o que se pretende investigar e compreender, contêm um contraponto concreto à tradição colonial da América Latina, que gesta e segue reproduzindo uma conformação peculiar às experiências de pensamento. A Figura 2 ilustra dois momentos distintos de Círculos de Cultura em espaços escolares:

Figura 2: Círculos de Cultura e Práticas Pedagógicas Escolares

\begin{tabular}{|l|l|}
\hline \multicolumn{1}{|c|}{$\begin{array}{c}\text { Escola Municipal Dario Bordin } \\
\text { União da Vitória/PR }\end{array}$} & \multicolumn{1}{c|}{$\begin{array}{c}\text { Escola Estadual Izelina Daldin Gaiovicz } \\
\text { General Carneiro/PR }\end{array}$} \\
\hline $\begin{array}{l}\text { A equipe da escola destacou o trabalho com projetos } \\
\text { extracurriculares, o que permitiu um maior diálogo } \\
\text { entre as crianças, educadores e comunidade - }\end{array}$ & $\begin{array}{l}\text { A partir de relatos de memórias coletivas e } \\
\text { individuais e da experiência da Equipe } \\
\text { Multidisciplinar que atua na implementação da Lei }\end{array}$ \\
interfaces entre currículo e os projetos; e surgiram \\
temas geradores como território e meio ambiente \\
(dimensão socioambiental), trabalho e os movimentos \\
em rede - interações com a escola, família, educadores, temáticas como educação, raça e \\
estudantes, nas dimensões econtexto territorial e de relações \\
e o desdobramento de temas geradores de estudo \\
culturais, direito à infância, à saúde, entre outras.
\end{tabular}

Olhar de professor, Ponta Grossa, v. 24, p. I-27, e-16773.018, 2021.

Disponível em <https://revistas2.uepg.br/index.php/olhardeprofessor> 


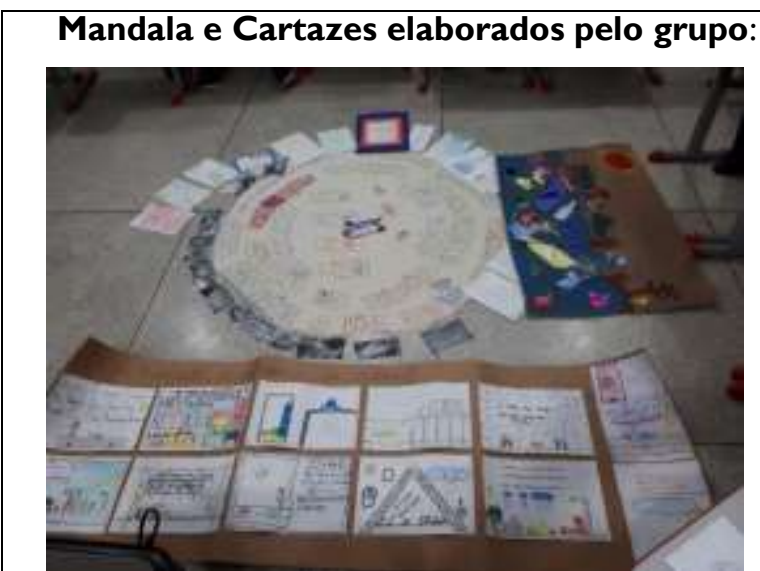

Neste encontro, foram iniciadas algumas reflexões sobre os temas geradores e os desafios para o trabalho educacional (político-pedagógico) em um bairro não central: a pobreza que se reflete no território e as possibilidades de efetivação de um currículo com maior participação das famílias e das crianças, considerando estes sujeitos de conhecimentos, saberes e experiências, que, em relação dialógica com a escola, podem contribuir e se envolver na garantia do direito à infância e escolarização.

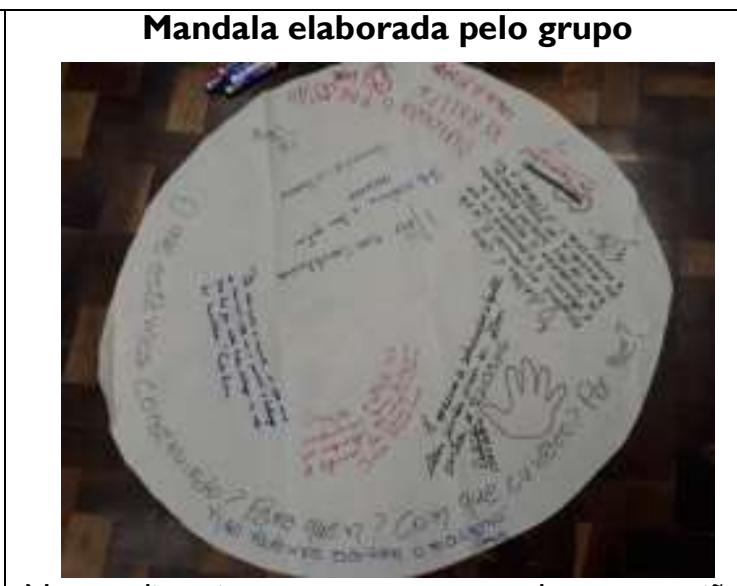

Neste dia, tivemos a presença de um ancião, morador da comunidade, convidado por funcionárias da escola a participar do Círculo de Cultura. Com alegria pelo convite, compartilhou saberes, sua história de vida e sua arte com a música ao tocar viola. Em suas narrativas, muitas vezes citou termos como era chamado: "crioulo", "preto”; para ele, algo já corriqueiro. Falou que seu pai (que também viveu na região do Contestado) morava em uma Fazenda, onde sua situação era de "liberdade", pós-abolição da escravatura, contudo, nas relações sociais o definiam como cativo. As narrativas deste senhor trouxeram sua vida, com ênfase em vários momentos de racismo, para as reflexões do grupo.

Fonte: Arquivo pessoal dos autores, 2019.

A vivência de Círculo de Cultura, ainda que nos limites do espaço escolar, ao trazer a vida concreta de pessoas da comunidade, contribui para reflexões que, por vezes, ficam no plano abstrato. Mirar sobre o mundo, suas (in)significâncias, sentidos, construir lampejos epistêmicos, éticos, políticos, estéticos é da ordem do humano; valorizar saberes, memórias, experiências é exercício de humanização. O mundo é do tamanho do conhecimento que temos dele (RIOS, 200I, p. 24), e ampliar os conhecimentos sobre o mundo tem sido ofício da educação, em sua historicidade. No entanto, em pleno século $\mathrm{XXI}$, nos deparamos com dilemas e desafios quanto à formação humana e a urgência de transformação do mundo em um ambiente de acolhimento de todos os seres.

Desde o século XIX, nas lutas por emancipação, temos na América Latina críticas ao eurocentrismo e a construção eurocêntrica de uma história universal. No século $X X$, de forma mais intensa, desenvolveram-se múltiplas análises sobre o colonialismo e seu exercício de poder totalizador. As críticas ao colonialismo o expressam como um sistema com consequências econômicas e políticas, com enraizamentos na cultura, na ciência, nos imaginários, nos modos de pensar, de conhecer e estar no mundo. As relações de saber e de poder na dinâmica colonial gestam a dominação epistemológica 
e, em oposição à razão moderna totalizadora, temos a reivindicação das diversidades. Trata-se, portanto, da superação do totalitarismo epistêmico.

Em cada Círculo de Cultura, num exercício horizontal de construção coletiva, temos procurado exercitar o descentramento da concepção eurocêntrica de história da humanidade. Reivindicamos desde a prática o exercício da autonomia intelectual e somamos às vozes que pedem pelo equilíbrio epistemológico no ordenamento do mundo, questão fundamental para que outros modos de organização política se tornem possíveis. Desse modo, não somente realizamos a crítica aos sistemas de dominação mental, cultural, econômica e política que gestam o colonialismo interno, como procuramos intervir na realidade desde nós mesmos.

Neste sentido, no exercício de escuta, de diálogo, procuramos nos afetar, em um exercício sentipensante, combinando corpo e coração, razão e amor (FALS BORDA, 20I5, p. 10), como princípio e práxis de sistematizações de saberes exercitando o reconhecimento das culturas, das memórias individuais e coletivas. Estes exercícios se dão na intrínseca relação entre filosofia e educação, promovendo convites a deslocamentos éticos, políticos e epistêmicos para a vivência da educação, para reorientar o pensamento e a ação no mundo, inspirada na ontologia ser mais, ou seja, na crítica às dominações cognitivas.

Círculos de Cultura, por fim, são espaços de educação e de investigação-ação-participativa (FALS BORDA, 20I5), de modo dialógico e dialético, sendo desde o planejar um processo participativo, compreendendo estudos bibliográficos e analíticos; levantamento, na região do Contestado, de experiências, memórias coletivas no sentido de reconhecimento de saberes silenciados e de modo processual sistematizar, problematizar, investigar, tematizar. Processo que, nas experiências aqui destacadas, estão em curso.

No contexto em que vivemos, de ataque real ao processo de redemocratização da sociedade brasileira, reler, revisar criticamente e vivenciar práticas educativas inspiradas em Paulo Freire tornamse urgentes e representam reafirmar a defesa da educação como prática de libertação.

\section{Considerações finais}

No compromisso e na esperança de construção de "inéditos viáveis", no estudo crítico e na reinvenção do legado freiriano, apresentamos, neste exercício de escrita, resultados parciais de um trabalho coletivo que procura articular ações de pesquisa e de extensão adotando Círculos de Cultura como princípio no campo educativo.

$\mathrm{Na}$ articulação entre pesquisa e extensão, num exercício de retroalimentação, de modo dialético e dialógico; com a realização de estudos bibliográficos, aproximando a Pedagogia Libertadora de Paulo Freire e o Programa de Transformação Intercultural da Filosofia proposto por Raúl Fornet- 
Educação e vivências interculturais: contribuições dos círculos de cultura em práticas libertadoras

Betancourt, temos procurado identificar convergências entre interculturalidade e dialogicidade para a construção de "inéditos viáveis", intervindo no instituído com iniciativas coletivas.

Através de Círculos de Cultura, dos ciclos ou grupo de estudos, temos sentido um significativo potencial epistêmico, ético e político no enlace entre interculturalidade e a teoria da ação dialógica de Paulo Freire, que em síntese representam um contraponto às formas de embrutecimento do outro e de reprodução de mentalidades colonizadas. Ao traçar convergências entre a filosofia intercultural, que tem em Raúl Fornet-Betancourt o principal representante, vimos nesta aproximação a possibilidade, a ser aprofundada, de revitalização e radicalização da pedagogia libertadora de Paulo Freire para construção de práxis polifônicas.

A filosofia intercultural como programa de transformação dos modos de pensar e estar no mundo situa-se no campo de um novo humanismo, anunciado por José Martí, Mariátegui, Fanon, Freire e outros. Enuncia e se soma a outros caminhos possíveis no quadro da educação crítica, também, explicada pelas chamadas "pedagogias insubmissas". Na obra Pedagogías insumisas: movimientos políticopedagógicos y memorias colectivas de educaciones otras en América Latina (MELGAREJO, 20I5), Sollano (2015, p. 15) explica:

[...] las pedagogías insumisas que nutren las páginas de este texto, constituyen referentes obligados en la reconstrucción genealógica del presente al mostrar no sólo lo que sus participantes - migrantes, mujeres, docentes, indígenas, trabajadores del campo, afrodescendientes, comunidades y movimientos sociales - han desplegado para atender necesidades específicas y crear las condiciones para que esa otra educación sea posible, sino además porque son productoras de sujetos y propuestas que colocan en la agenda pública cuestiones que, a pesar de ser parte de la vida de los pueblos, fueron olvidadas, soterradas o negadas en nombre de la regulación hegemónica del Estado, la sociedad y las instituciones. Son, asimismo apuestas político-pedagógicas que muestran el potencial heurístico e histórico que todo proceso de formación implica cuando dota de sentido y significación a la experiencia y abre la posibilidad para generar saberes que pueden ser la base para la construcción de otras miradas, otros lenguajes, otras lógicas de pensamiento, otras escrituras, en síntesis, otras formas de construir nuestro lazo con la vida, con la sociedad y con la naturaliza. ${ }^{19}$

\footnotetext{
19 Tradução dos autores: "[...] as pedagogias insubmissas que alimentam as páginas deste texto, constituem referências obrigatórias na reconstrução genealógica do presente, ao mostrar não só o que seus participantes migrantes, mulheres, professores, indígenas, trabalhadores do campo, afrodescendentes, comunidades e movimentos sociais - têm se desdobrado para atender necessidades específicas e criar as condições para que essa outra educação seja possível, mas também por serem produtoras de sujeitos e propostas que colocam na agenda pública questões que, apesar de fazerem parte da vida dos povos, foram esquecidas, enterradas ou negadas em nome da regulação hegemônica do Estado, da sociedade e das instituições. São também apostas políticopedagógicas que mostram o potencial heurístico e histórico que todo processo de formação implica ao dar sentido e significação à experiência e abrir a possibilidade de gerar conhecimentos que podem servir de base para a construção de outros olhares, outras linguagens, outras lógicas de pensamento, outros escritos, enfim, outras formas de construir nosso vínculo com a vida, com a sociedade e com a natureza".
} 
A vivência intercultural atua na construção de percursos éticos, políticos, educativos e culturais, que visa desconstruir subordinações, alienações, práticas massificadoras da cultura, tais como os fenômenos da cultura de massa em contraposição à cultura popular, desescolarizando a escola do seu modo colonial ainda vigente, desmistificando a noção de cultura como enciclopédica ou erudita, é porta voz de um projeto descolonizador.

Freire propõe um processo educativo integral, em que a ação pedagógica se efetua no horizonte dialógico intersubjetivo e comunitário, mediante a transformação das estruturas que oprimem o educando, não se fazendo apenas inteligência teórica ou moral, mas realizando uma revolução copernicana em pedagogia, ainda longe de ser compreendida (DUSSEL, 2012, p. 427-443). Por sua vez, Fornet-Betancourt destaca a necessidade de superação da razão monocultural e, assim como Freire, problematiza o papel dos intelectuais, os quais, no seu entendimento, precisam se reeducar em vivências interculturais, como formação intersubjetiva, ética, com e entre outros.

A organização e o desenvolvimento de círculos de cultura visam a promoção de práticas que vivenciem princípios de construção coletiva, dialógica e participativa. A cada encontro, é proposta uma avaliação, sempre na busca de construir parâmetros de autoanálise das práticas. Essas ações de autorreflexão proporcionam criar e recriar leituras de mundo e de textos, sobretudo, permitem novas "tessituras" sobre alternatividades na educação, ou seja, produção de conhecimentos em comunidades pedagógicas comprometidas com a transformação social, embebidas da interculturalidade e libertação. Círculos de Cultura são territórios nos quais cada pessoa é acolhida como sujeito de seu pensar.

\section{Referências}

ADORNO, T.W.; HORKHEIMER, M. Dialética do esclarecimento: fragmentos filosóficos. 2.ed. Rio de Janeiro: Jorge Zahar, 1986.

ALMEIDA, S. Racismo Estrutural: São Paulo: Sueli Carneiro; Pólen Livros, 2019.

BRASIL. Constituição da República Federativa do Brasil. Brasília, DF: Senado Federal: Centro Gráfico, 1988.

BRASIL. Lei n. 13.005, de 25 de junho de 2014. Aprova o Plano Nacional de Educação - PNE e dá outras providências. Disponível em: http://www.planalto.gov.br/ccivil_03/_ato20II 20I4/20 I4/lei//I 3005.htm. Acesso em: 10 ago. 2020.

BRASIL. Resolução n. 7, de 18 de dezembro de 20I8. Conselho Nacional de Educação. Câmara de Educação Superior. Estabelece as Diretrizes para a Extensão na Educação Superior Brasileira e regimenta o disposto na Meta 12.7 da Lei $n^{\circ}$ 13.005/20 I4, que aprova o Plano Nacional de Educação - PNE 2014-2024 e dá outras providências. Disponível em: http://portal.mec.gov.br/index.php?option=com docman\&view $=$ download\&alias $=10425 \mathrm{I}-\mathrm{rces} 007$ I8\&category_slug=dezembro-2018-pdf\&Itemid=30192. Acesso em: 10 ago. 2020. 
COSTA, B. B. Paulo Freire e os Círculos de Cultura: uma pedagogia da humanização. In: SPIGOLON, N. I.; CAMPOS, C. B. G. (org.). Círculos de Cultura: teoria, práticas e práxis. Curitiba: CRV, 2016.

DOURADO, L. F. Diretrizes Curriculares Nacionais para a formação inicial e continuada dos profissionais do magistério da educação básica: concepções e desafios. Educação \& Sociedade, Campinas, v. 36, n. I3I, p. 299-324, abr.-jun. 2015.

DUSSEL, E. Ética da Libertação: na idade da globalização e da exclusão. 4. ed. Petrópolis: Vozes, 2012.

DUSSEL, E. Europa, modernidade e eurocentrismo. In: LANDER, E. (org.). A colonialidade do saber: eurocentrismo e ciências sociais. Perspectivas latino-americanas. Colección Sur, CLACSO, Ciudad Autónoma de Buenos Aires, Argentina, set. 2005.

FANON, F. Os condenados da terra. Juiz de Fora: Ed. UFJF, 2005.

FALS BORDA, O. Una sociología sentipensante para América Latina. México: Siglo XXI Editores; Buenos Aires: CLACSO, 2015.

FAUNDEZ, A.; FREIRE, P. Por uma pedagogia da pergunta. Rio de Janeiro: Paz e Terra, 1985.

FORNET-BETANCOURT, R. Transformación intercultural de la filosofia latino-americana: ejercicios teóricos y práticos de la filosofía intercultural en el contexto de la globalización. Bilbao: Desclée de Brouwer, 200I.

FORNET-BETANCOURT, R. Interculturalidade, críticas, diálogos e perspectivas. São Leopoldo: Nova Harmonia, 2004.

FORNET-BETANCOURT, R. La interculturalidad a prueba. Aachen: Revista Concórdia, Band 43, 2006.

FRAGA, N. C. Contestado em guerra: 100 anos do massacre insepulcro do Brasil - $1912-2012$. Florianópolis: Insular, 2012.

FREIRE, P. Pedagogia do oprimido. 28. ed. Rio de Janeiro: Paz e Terra, 1987.

FREIRE, P. Educação como prática da liberdade. 26. ed. São Paulo: Paz e Terra, 2002.

FREIRE, P. Extensão ou comunicação? I4. ed. Rio de Janeiro: Paz e Terra, 2010.

FREIRE, P. Pedagogia da Esperança. 6. ed. Rio de Janeiro: Paz e Terra, 1999a.

FREIRE, P. Pedagogia da Autonomia: saberes necessários à prática educativa. I3. ed. São Paulo: Paz e Terra, 1999b.

GADOTTI, M. Lições de Freire. Rev. Fac. Educ., São Paulo, v. 23, n.I-2, jan./dec. 1997.

GRAMSCl, A. Os intelectuais e a Organização da Cultura. 4. ed., Rio de Janeiro: Civilização Brasileira, 1982.

GEERTZ, C. A interpretação das culturas. Rio de Janeiro: LTC, 1989.

Olhar de professor, Ponta Grossa, v. 24, p. I-27, e-16773.018, 2021.

Disponível em <https://revistas2.uepg.br/index.php/olhardeprofessor> 
hooks, b. Ensinando a Transgredir: a educação como prática da liberdade. São Paulo: Martins Fontes, 2013.

hooks, b. O feminismo é para todo mundo: políticas arrebatadoras. Rio de Janeiro: Editora Rosa dos Tempos, 2018.

LEHER, R. Os anos Lula: contribuições para um balanço crítico 2003-2010., Rio de Janeiro: Garamond, 2010.

MENESES. M. M. de. A Filosofia feminista desde os olhares da filosofia intercultural: uma reflexão entre margens. In: PACHECO, J. (org.). Mulher \& Filosofia: as relações de gênero nopensamento filosófico. Porto Alegre: Editora Fi, 2015.

MELGAREJO, P. M. (coord.). Pedagogías insumisas: movimentos político-pedagógicos y memorias colectivas de educaciones otras en América Latina. Universidad de Ciencias y Artes de ChiapasCentro de Estudios Superiores de México y Centroamérica: Educación para las Ciencias en Chiapas, Juan Pablos Editor, México, 2015.

QUIJANO, A. Colonialidade do poder, eurocentrismo e América Latina. In: LANDER, E. (Org.). A colonialidade do saber: Eurocentrismo e Ciências Sociais. Perspectivas Latino-Americanas. Buenos Aires: CLACSO, 2005.

RIBEIRO, D. A universidade necessária. Rio de Janeiro: Paz e Terra, 1975.

RIOS, T. A. Compreender e ensinar: por uma docência de melhor qualidade. São Paulo: Cortez, 2001.

SANTOS, M. Por uma outra globalização: do pensamento único a consciência universal. 9.ed Rio de Janeiro: Record, 2002.

VERAS, D; MENDONÇA, D. Educação popular e reforma universitária: Paulo Freire e a criação do Serviço de Extensão Cultural da Universidade de Recife (1962-1 964). In:

Estudos Universitários: revista da cultura da Universidade Federal de Pernambuco. V.24/25, n.5/6. Recife: UFPE, 2008/2009.

VIEIRA PINTO, A. A questão da universidade. São Paulo: Cortez, 1994.

VIEIRA PINTO, A. Consciência e Realidade Nacional. v. II. Rio de Janeiro: ISEB, 1960.

Recebido em: 29 de agosto de 2020.

Versão corrigida recebida em: 07 de novembro de 2020.

Aceito em: 07 de novembro de 2020.

Publicado online em: 19 de março de 2021.

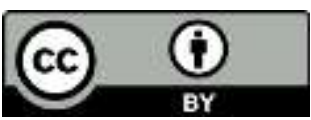

Olhar de professor, Ponta Grossa, v. 24, p. I-27, e-16773.018, 2021.

Disponível em <https://revistas2.uepg.br/index.php/olhardeprofessor> 